\title{
The effect of patterns of rumen fermentation on the response by dairy cows to dietary protein concentration
}

\author{
BY J. A. LEES 1 , J. D. OLDHA Mㄹ, W. HARESIGN ${ }^{1}$ AND P. C. GARNSWORTHY ${ }^{1 *}$ \\ ${ }^{1}$ University of Nottingham School of Agriculture, Sutton Bonington, Loughborough, \\ Leics. LEI2 5RD \\ ${ }^{2}$ Edinburgh School of Agriculture, West Mains Rd, Edinburgh EH9 $3 J G$
}

(Received 17 April 1989-Accepted 22 September 1989)

\begin{abstract}
Four groups of seven dairy cows were given hay plus high-fibre concentrates based on sugar-beet feed (hay-concentrate, 40:60 w/w) or high-starch concentrates based on flaked maize (hay-concentrate, $20: 80 \mathrm{w} / \mathrm{w}$ ), with a crude protein (nitrogen $\times 6.25$ ) content of either 160 or $220 \mathrm{~g} / \mathrm{kg}$ dry matter, over weeks 4-18 of lactation. Performance during week 3 of lactation, when all cows were fed on a standard ration, was used as a covariate. For diets with a high-fibre content, higher protein concentrations led to increases in yields of milk and milk fat, with no effect on live-weight loss. For diets with a high-starch content, higher protein concentrations did not affect milk yield or composition but resulted in an increase in live weight rather than a decrease. Diets with a high-starch content led to increased proportions of propionic acid in the rumen and increased concentrations of insulin in the blood. It is concluded that the source of carbohydrate needs to be taken into account when predicting the response to protein supply by dairy cows.
\end{abstract}

Dietary carbohydrate: Dietary protein: Rumen fermentation: Cow

The proposals put forward by the Agricultural Research Council $(1980,1984)$ for estimating protein requirements in ruminants, suggest that microbial protein supply is insufficient for milk production in high-yielding dairy cows, and that there will be a response to an increase in total amino acid supply to the small intestine, achieved by the inclusion of protein sources which are relatively undegraded in the rumen. Furthermore, it has been suggested that the supply of amino acids to body tissues can influence the extent to which dairy cows mobilize body-fat reserves in support of milk production in early lactation (Ørskov et al. 1981; Garnsworthy \& Jones, 1987; Jones \& Garnsworthy, 1988). However, in other reports, animals have shown increased milk yield and reduced weight loss with increasing protein intake (Oldham et al. 1979; Cowan et al. 1981).

In trials in which responses in energy balance of dairy cows to increased protein intake have been measured, differences in energy intake have often been achieved by altering the basal diet, in particular the concentrate:forage ratio. No account has been taken of how these changes influence the response in milk production although it is well established that the nature of the basal diet, especially its influence on the balance of volatile fatty acids in the rumen, has a major effect on the partitioning of nutrients between milk secretion and body tissue. The present paper describes a trial designed to measure the response of dairy cows to protein supplements given with iso-energetic diets formulated to maintain widely differing patterns of rumen fermentation. 
Table 1. Composition of concentrates with a high-fibre $(F)$ or high-starch $(S)$ content and with a low $(L)$ or high $(H)$ concentration of protein $(\mathrm{g} / \mathrm{kg}$ as fed)

\begin{tabular}{lccccc}
\hline & & \multicolumn{5}{c}{ Concentrate } \\
\cline { 3 - 6 } & $\begin{array}{c}\text { Pre- } \\
\text { treatment }\end{array}$ & FL & FH & SL & SH \\
\hline Barley & 413 & 352 & 245 & 318 & 222 \\
Molassed sugar-beet feed & 150 & 350 & 245 & - & - \\
Flaked maize & 230 & - & - & 402 & 280 \\
Soya-bean meal & 150 & - & 240 & - & 240 \\
Ground maize & - & 180 & 125 & 162 & 113 \\
Fishmeal & - & - & 60 & - & 60 \\
Wheatfeed & 7 & 50 & 35 & 50 & 35 \\
Urea & 50 & 50 & -50 & 50 & 50 \\
Minerals + vitamins & & & & & \\
\hline
\end{tabular}

MATERIAL AND METHODS

Animals and management

Immediately after autumn calving, twelve British Friesian cows and sixteen heifers were housed in a double-stall cowshed, bedded on straw. Straw consumption was not measured, but did not appear to be of any significance. The animals were milked twice daily at 06.00 and 15.45 hours and offered concentrates and hay individually, with free access to water. The concentrates were offered in equal amounts at each milking and at 09.30 hours, and the hay at 09.30 hours and following the afternoon milking.

\section{Treatments}

After calving, all animals received $4 \mathrm{~kg} / \mathrm{d}$ of a pretreatment concentrate (Table 1) and $4 \mathrm{~kg}$ hay/d (air-dry basis). These amounts were gradually increased so that by day 14 of lactation, cows and heifers were offered concentrates at the rate of 12.5 or $11.0 \mathrm{~kg} / \mathrm{d}$ respectively, and hay at the rate of 6.5 or $6.0 \mathrm{~kg} / \mathrm{d}$ respectively. In the fourth week of lactation, animals were assigned to four groups, each balanced as far as possible for lactation number (including parities within cows), live weight and performance in week 3. Each group was offered one of four experimental diets which were given during weeks 4-18 of lactation and consisted of two concentrate types, based on either sugar-beet feed (fibrous; F) or flaked maize (starchy; S), arranged factorially with two concentrations of crude protein (nitrogen $\times 6.25 ; \mathrm{CP})$; low $(60 \mathrm{~g} \mathrm{CP} / \mathrm{kg}$ dry matter (DM); L) or high $(220 \mathrm{~g} \mathrm{CP} / \mathrm{kg} \mathrm{DM} ; \mathrm{H})$. The concentrate formulations, designated FL, FH, SL and SH, are given in Table 1.

Cows or heifers respectively were offered (air-dry basis) 11.0 or $10.0 \mathrm{~kg}$ concentrates $/ \mathrm{d}$ plus 7.5 or $7.0 \mathrm{~kg}$ hay/d in the FL and FH groups (hay-concentrate, $40: 60 \mathrm{w} / \mathrm{w}$ ), and 12.5 or $11.5 \mathrm{~kg}$ concentrates/d plus 3.5 or $3.0 \mathrm{~kg}$ hay/d in the SL and $\mathrm{SH}$ groups (hay-concentrate, 20:80 w/w). These diets were designed to be iso-energetic (on an estimated metabolizable energy (ME) basis) within age-groups and to provide sufficient ME for $23 \mathrm{~kg}$ milk/d in cows or $20 \mathrm{~kg}$ milk/d in heifers. Protein degradability (DG) was calculated to be $0.80,0.65,0.75$ and 0.61 for diets FL. FH, SL and SH respectively, using values for individual ingredients obtained from the Agricultural Research Council (1980).

\section{Measurements and analysis}

Individual milk yields were recorded daily and the weekly mean yield calculated. Milk samples were collected from two consecutive milkings once weekly. Milk fat content was determined using a Milko-Tester Mk II (A/S N Foss Electric UK Ltd) and protein content 
using a Pro-milk Mk II (A/S N Foss Electric UK Ltd). Live weights were recorded twice each week and the mean for each week used in analyses. Weekly food samples were bulked for each calendar month and analysed for $\mathrm{N}$, organic matter and acid-detergent fibre.

Blood samples were taken at hourly intervals over $24 \mathrm{~h}$ during week 11 of lactation from an indwelling jugular vein catheter and analysed for plasma insulin concentrations using a specific double-antibody radioimmunoassay (Beeby \& Swan, 1983).

Rumen-fluid samples were obtained by stomach tube from all animals at 09.00 and 14.00 hours during weeks 9 and 16 of lactation. The samples were bulked by volume for individual animals on each day and their volatile fatty acid concentrations determined using gas-liquid chromatography.

\section{Digestibility determinations}

Two cows and two heifers from each treatment group were offered concentrates containing $5 \mathrm{~g}$ chromic oxide $/ \mathrm{kg}$ between weeks 13 and 19 of lactation in place of their normal concentrates. After a $7 \mathrm{~d}$ equilibration period, faecal samples were collected by grab sampling at 09.00 and 15.00 hours daily for $7 \mathrm{~d}$ and bulked for individual animals within days, after DM determination. Additional faecal samples were collected at three-hourly intervals for $48 \mathrm{~h}$ during the collection period and bulked for individual cows according to time of collection to allow correction of the daily samples for diurnal variation. All faecal samples were analysed for $\mathrm{Cr}_{2} \mathrm{O}_{3}$ (Cheong \& Salt, 1968), crude protein, organic matter and acid-detergent fibre contents.

\section{Degradability determination}

Four lactating cows, each fitted with a rumen fistula, were fed on the four treatment rations in a Latin-square design. They were fed and milked in a similar way to the cows on the production trial, except that the middle feed was given at 11.00 hours instead of 09.30 hours. For each treatment ration, six polyester bags (pore size $43 \mu \mathrm{m}$; Sericol, London) containing $10 \mathrm{~g}$ of the appropriate concentrate which had been milled through a $1 \mathrm{~mm}$ screen, were inserted into the rumen of each cow. Bags were removed after $2 \mathrm{~min}, 3,6,12$, 24 and $36 \mathrm{~h}$ incubation, washed in cold, running water until the water ran clear and dried at $60^{\circ}$. The DM and $\mathrm{N}$ losses from each bag were measured and fitted to the exponential model of Ørskov \& Mcdonald (1979):

$$
p=a+b\left(1-\mathrm{e}^{-c t}\right)
$$

where $p$ is the amount of DM or $\mathrm{N}$ degraded at time $t, a$ is the immediately soluble fraction, $b$ is the potentially degradable fraction, and $c$ is the fractional rate of degradation of $b$. The effective DG was then calculated from the estimates of $a, b$ and $c$ constants, assuming a fractional outflow rate of solid particles from the rumen $(k)$ of $0.08 / \mathrm{h}$ using the equation:

$$
\mathrm{DG}=a+\frac{b c}{c+k}
$$

\section{Statistical analysis}

The values were analysed using a $2 \times 2 \times 2$ factorial design (diet type, protein concentration, cows $v$. heifers) with performance in week 3 as a covariate for responses in the production trial.

Although differences between cows and heifers were found in absolute means for intake (heifers $12.7 \mathrm{~kg} \mathrm{DM} / \mathrm{d}$, cows $14.2 \mathrm{~kg} \mathrm{DM} / \mathrm{d}$ ) and milk production (heifers 22.2 litres/d, cows 23.0 litres $/ \mathrm{d}$ ), there was no significant effect of parity on response to diet or protein treatments. Therefore, only the effects of diet and protein concentration are presented. The use of covariance was significant in all cases so means presented have been corrected for the covariate where applicable. 
Table 2. Chemical composition of hay and treatment concentrates with a high-fibre $(F)$ or high-starch $(S)$ content and with a low $(L)$ or high $(H)$ concentration of protein*

\begin{tabular}{crrrrr}
\hline & & & & & \\
& & & & \\
& & & & \\
& FL & FH & SL & SH & Hay \\
\hline Dry matter $(\mathrm{g} / \mathrm{kg})$ & 860 & 865 & 856 & 861 & 835 \\
Crude protein $(\mathrm{g} / \mathrm{kg} \mathrm{DM})$ & 158 & 222 & 158 & 218 & 68 \\
Acid-detergent fibre $(\mathrm{g} / \mathrm{kg} \mathrm{DM})$ & 88 & 86 & 31 & 42 & 425 \\
\hline
\end{tabular}

DM, dry matter.

* For details of composition, see Table 1.

Table 3. Mean food intake, milk production and live-weight change over weeks 4-18 of lactation for each group of cows given diets* with a high-fibre $(F)$ or high-starch $(S)$ content and a low $(L)$ or high $(H)$ concentration of protein (corrected for performance in week 3)

\begin{tabular}{|c|c|c|c|c|c|}
\hline \multirow[t]{2}{*}{ Dietary treatment ... } & \multicolumn{2}{|c|}{ High-fibre } & \multicolumn{2}{|c|}{ High-starch } & \multirow[b]{2}{*}{ SED } \\
\hline & FL & $\mathrm{FH}$ & SL & $\mathrm{SH}$ & \\
\hline \multicolumn{6}{|l|}{ Intake } \\
\hline Concentrates (kg DM/d) & $8 \cdot 8^{a}$ & $8 \cdot 9^{a}$ & $9 \cdot 4^{b}$ & $9 \cdot 7^{c}$ & $0 \cdot 13$ \\
\hline Hay $(\mathrm{kg} \mathrm{DM} / \mathrm{d})$ & $5 \cdot 6^{\mathrm{a}}$ & $5 \cdot 6^{a}$ & $2 \cdot 6^{\mathrm{b}}$ & $2 \cdot 7^{\mathrm{b}}$ & $0 \cdot 11$ \\
\hline Total $(\mathrm{kg} \mathrm{DM} / \mathrm{d})$ & $14 \cdot 4^{\mathrm{a}}$ & $14 \cdot 6^{\mathrm{a}}$ & $12 \cdot 0^{\mathrm{b}}$ & $12 \cdot 4^{4}$ & $0 \cdot 15$ \\
\hline \multicolumn{6}{|l|}{ Yield } \\
\hline $\operatorname{Milk}(\mathrm{kg} / \mathrm{d})$ & $20 \cdot 6^{\mathrm{a}}$ & $23 \cdot 3^{b}$ & $21 \cdot 7^{\mathrm{ab}}$ & $24 \cdot 5^{b}$ & $1 \cdot 25$ \\
\hline Fat-corrected milk $(\mathrm{kg} / \mathrm{d})$ & $20 \cdot 3^{a}$ & $23 \cdot 6^{\mathrm{l}}$ & $17 \cdot 9^{\mathrm{a}}$ & $19 \cdot 6^{a}$ & 0.99 \\
\hline Fat $(\mathrm{g} / \mathrm{d})$ & $803^{a}$ & $953^{\mathrm{h}}$ & $616^{\mathrm{c}}$ & $654^{\circ}$ & $52 \cdot 1$ \\
\hline Protein $(\mathrm{g} / \mathrm{d})$ & $604^{\mathrm{a}}$ & $701^{\mathrm{b}}$ & $642^{\mathrm{ab}}$ & $737^{b}$ & $43 \cdot 4$ \\
\hline \multicolumn{6}{|l|}{ Concentration } \\
\hline Fat $(\mathrm{g} / \mathrm{kg})$ & $39 \cdot 0^{a}$ & $40 \cdot 9^{a}$ & $28 \cdot 4^{\mathrm{b}}$ & $26 \cdot 7^{b}$ & $2 \cdot 65$ \\
\hline Protein $(\mathrm{g} / \mathrm{kg})$ & $29 \cdot 3^{a}$ & $30 \cdot 1^{\mathrm{a}}$ & $29 \cdot 6^{\mathrm{a}}$ & $30 \cdot 1^{\mathrm{a}}$ & 0.96 \\
\hline $\begin{array}{l}\text { Live-weight change, } \\
\text { weeks } 3-18(\mathrm{~kg})\end{array}$ & $-15^{a b}$ & $-18^{a}$ & $-22^{a}$ & $+5^{b}$ & $10 \cdot 4$ \\
\hline
\end{tabular}

SED, standard error of difference; DM, dry matter.

a,b, Means in the same horizontal row with different superscript letters were significantly different $(P<0-05)$.

* For details, see Tables 1 and 2.

\section{RESULTS}

\section{Food intake}

Chemical analysis of the concentrates and hay are shown in Table 2 . Animals offered the high-protein concentrates refused less and, therefore, had higher DM intakes but this was only significant $(P<0.05)$ for the high-starch diets (Table 3 ).

\section{Milk yield and composition}

Treatment means for milk yield and composition are shown in Table 3 . Higher dietary protein concentrations led to increased milk yields $(P<0.01)$, but within-diet types the increase was only significant for the high-fibre diets $(P<0-05)$. Cows given the concentrates with a high-fibre content had higher milk fat contents $(P<0.001)$ and fat yields $(P<$ $0.001)$. The higher protein content of the FH diet led to a further increase $(P<0.05)$ in fat 

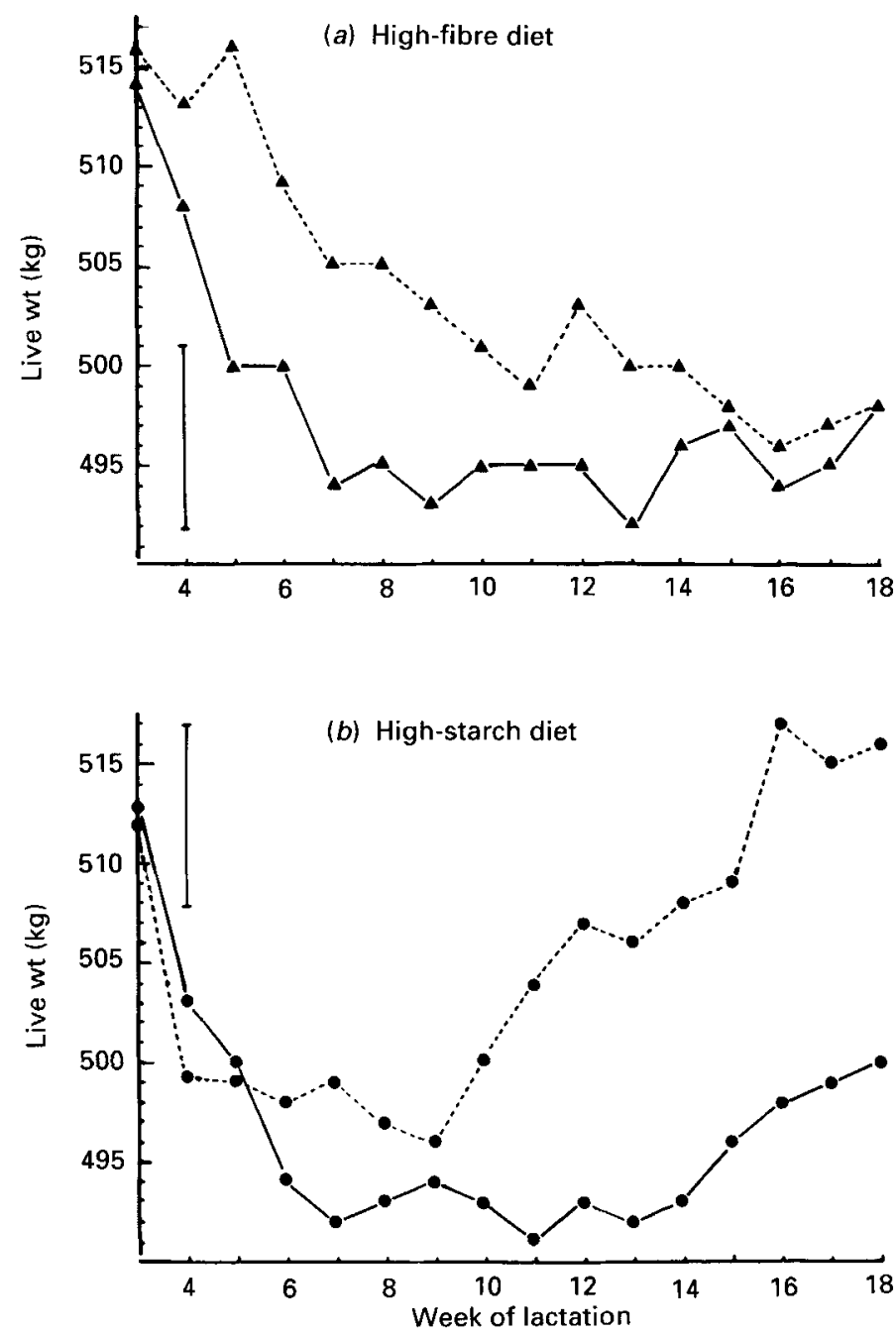

Fig. 1. Live weight in relation to week of lactation, adjusted for covariance. Each point represents the mean for seven animals offered $(a)$ a high-fibre $(\boldsymbol{\Delta})$ or $(b)$ a high-starch $(\boldsymbol{O})$ diet and high $(-\ldots)$ or low (-_ levels of crude protein (nitrogen $\times 6.25$ ). The error bars represent the standard error of the difference for comparing means in different treatment groups. For details of diets see Tables 1 and 2.

yield. Milk fat content decreased and yield increased with increasing protein concentration for the high-starch diets but the differences were not significant. Fat-corrected milk yield was greater $(P<0.01)$ for diet FH than for the other three diets. Higher dietary protein concentrations resulted in higher milk protein concentrations (not significant) and yields $(P<0.05)$ for both diet types, but for protein yield only the difference between the highfibre diets was significant.

\section{Live-weight change}

The pattern of live-weight change varied with diet type $(P<0 \cdot 001)$ over the treatment period, due mainly to the difference in response to increased dietary protein concentration $(P<0.05)$ between diet types (Fig. 1). Whereas animals offered diets FL, SL and FH lost 


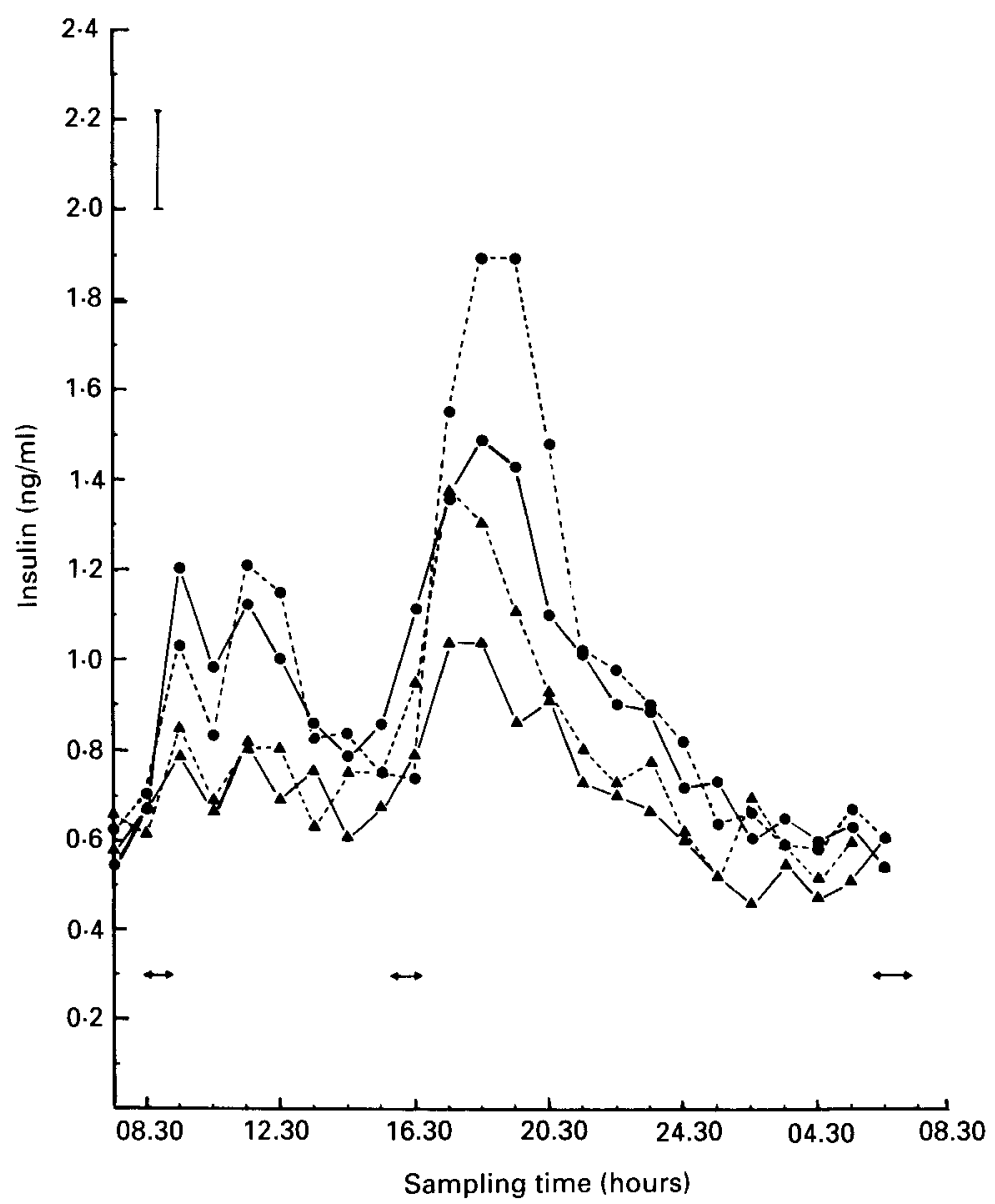

Fig. 2. Mean insulin concentrations in plasma samples collected hourly over a $24 \mathrm{~h}$ period from animals in week 11 of lactation. Each point represents the mean for seven animals offered a high-fibre $(\mathbf{A})$ or high-starch $(\boldsymbol{O})$ diet with high (---) or low ( - ) levels of crude protein (nitrogen $\times 6 \cdot 25)$. ( $\leftrightarrow$ ) Periods during which food was offered. The error bar represents the standard error of the difference for comparing means in different treatment groups. For details of diets see Tables 1 and 2.

approximately 0.03 of their week 3 live weight by week 18 , those on diet SH gained weight after week 9 , so that by week 18 they were heavier than at week 3 (Table 3 ). On high-fibre diets, higher protein delayed the fall in live weight whereas on high-starch diets it hastened recovery. The responses to different diets were very similar in cows and heifers. No significant interaction was found between parity and diet type or protein level for liveweight change. For each diet, cows tended to lose 4-10 kg more than heifers between weeks 3 and 18 , but the difference was not significant.

\section{Blood composition}

The high-starch diets tended to promote higher $(P<0.05)$ concentrations of plasma insulin and greater postprandial peaks over the $24 \mathrm{~h}$ sampling period (Fig. 2). Animals on the highprotein diets showed greater postprandial peaks after the afternoon feed than those on the corresponding low-protein diets, the magnitude of the difference being similar for both carbohydrate sources. 
Table 4. Mean apparent digestibility coefficients for dry matter, crude protein (nitrogen $\times 6 \cdot 25$ ), acid-detergent fibre and organic matter of diets with a high-fibre $(F)$ or high-starch $(S)$ content and a low $(L)$ or high $(H)$ concentration of protein*.

\begin{tabular}{lccccc}
\hline \hline Dietary treatment ... & FL & FH & SL & SH & SED \\
\hline Digestibility of: & & & & & \\
Dry matter & $0.59^{\mathrm{a}}$ & $0.65^{\mathrm{b}}$ & $0.67^{\mathrm{b}}$ & $0.64^{\mathrm{b}}$ & 0.019 \\
Crude protein & $0.56^{\mathrm{a}}$ & $0.71^{\mathrm{b}}$ & $0.71^{\mathrm{b}}$ & $0.75^{\mathrm{b}}$ & 0.024 \\
Acid-detergent fibre & $0.38^{\mathrm{a}}$ & $0.42^{\mathrm{a}}$ & $0.16^{\mathrm{b}}$ & $0.09^{\mathrm{b}}$ & 0.092 \\
Organic matter & $0.61^{\mathrm{s}}$ & $0.67^{\mathrm{b}}$ & $0.69^{\mathrm{b}}$ & $0.67^{\mathrm{b}}$ & 0.018 \\
\hline
\end{tabular}

SED, standard error of difference.

${ }^{a, b}$ Means in the same horizontal row with different superscript letters were significantly different $(P<0.05)$.

* For details, see Tables 1 and 2.

Table 5. Mean molar proportions of volatile fatty acids in samples of rumen fluid taken in weeks 9 and 16 of lactation for each diet type $\dagger$

\begin{tabular}{|c|c|c|c|c|c|c|}
\hline \multirow[b]{2}{*}{ Diet type... } & \multicolumn{3}{|c|}{ Week 9} & \multicolumn{3}{|c|}{ Week 16} \\
\hline & Fibre & Starch & SED & Fibre & Starch & SED \\
\hline Acetate (A) & 0.668 & $0 \cdot 609$ & $0 \cdot 020^{* *}$ & 0.648 & 0.602 & 0.025 \\
\hline Propionate (P) & $0 \cdot 177$ & $0 \cdot 257$ & $0.016^{* * * *}$ & $0 \cdot 186$ & $0 \cdot 274$ & $0.022^{* * * *}$ \\
\hline Butyrate (B) & $0 \cdot 155$ & $0 \cdot 133$ & 0.013 & 0.166 & 0.125 & $0.013^{* *}$ \\
\hline$A+B: P$ & 4.66 & $3-06$ & $0.275^{* * *}$ & 4.49 & $3 \cdot 00$ & $0.335^{* * *}$ \\
\hline
\end{tabular}

SED, standard error of difference.

$\dagger$ For details, see Tables 1 and 2 .

${ }^{* *} P<0.01,{ }^{* * *} P<0.001$.

\section{Digestibility coefficients}

The digestibility of acid-detergent fibre was very low for the high-starch diets but not so low for the high-fibre diets $(P<0.05)$. For the high-fibre diets, increasing the protein concentration led to higher $(P<0.05)$ digestibility coefficients for DM, CP and organic matter (Table 4).

\section{$D G$ measurements}

The DG trial was designed as a $4 \times 4$ Latin square but values from one period were not available so it was analysed as an incomplete Latin square.

The determined DG of protein were 0.62, 0.44, 0.62 and 0.46 for diets FL, FH, SL and $\mathrm{SH}$ respectively. The difference between low- and high-protein concentrates was significant $(P<0.01)$.

\section{Molar proportions of volatile fatty acids}

Molar proportions of volatile fatty acids were not affected by protein concentration. Diets with a high-fibre content produced higher proportions of acetate and butyrate but lower proportions of propionate at both stages of lactation (Table 5). This resulted in greater $(P$ $<0.001)$ values for the acetate + butyrate: propionate ratio for high-fibre than for highstarch diets. 


\section{DISCUSSION}

The achievement of distinctly different patterns of rumen fermentation with the two basal diets was crucial to the experimental design. This objective was achieved since the high-fibre diets resulted in higher proportions of acetate and butyrate whilst the high-starch diets promoted higher proportions of propionate. The differences in end-products of digestion were reflected in differences in insulin status between the two types of diet, higher concentrations of insulin being associated with the high-starch diets. High concentrations of plasma insulin have been reported from other experiments with low-fibre, highconcentrate rations (Trenkle, 1970; Bhattacharya \& Alulu, 1975; Jenny \& Polan, 1975; Sutton et al. 1988). The second objective was to supply more protein to the small intestine with the high-protein diets. Measured DG values, although consistently lower than predicted values, suggest that this was achieved.

The main response to diet type was the high content and yield of milk fat with diets having a high-fibre content. These responses were not surprising since other workers have found reduced concentrations of milk fat with reduced forage:concentrate ratios (Sutton et al. 1980, 1987), and the effect is apparently enhanced when, as in the present experiment, fibrous carbohydrate sources are replaced by starchy ones (Davis et al. 1983).

Milk yield increased in response to higher protein concentrations with both diet types and this was the main factor responsible for the effect of protein concentration on fat, protein and lactose yields. Although the diets were designed to be iso-energetic within cow groups or parities, calculated intakes of ME were 147, 151, 144 and $145 \mathrm{MJ} / \mathrm{d}$ for diets FL, $\mathrm{FH}, \mathrm{SL}$ and SH respectively. Differences in the digestibility of organic matter of the four rations were found which probably account for the differences in intake of concentrates and hay. These could have resulted in further differences in true ME intake. Responses in milk production to protein supplementation have been attributed to effects of protein on ration digestibility and food intake (Cowan et al. 1981). This could account for part of the response with the high-fibre diets, but in the high-starch diets the main response to increased protein concentration was a decrease in weight loss. This suggests that different mechanisms were operating with the two different diet types.

One theory to explain the effect of undegradable protein on fat mobilization is that the non-essential amino acids aspartate and glutamate, provided by the undegradable protein, contribute to the formation of oxaloacetate, an intermediate in both the tricarboxylic acid (TCA) cycle and gluconeogensis (MacRae, 1983), effectively improving the energy and glucose supply. It is possible that an increased oxaloacetate supply may promote fat mobilization to support the demands of the TCA cycle for acetyl-CoA, which would explain the increased weight loss reported in some experiments (Ørskov et al. 1981; Garnsworthy \& Jones, 1987; Jones \& Garnsworthy, 1988).

It appears that a similar response in fat mobilization to increased protein supply was not observed with the high-starch diets because of the overriding effect of protein concentration on insulin status in these animals, particularly the high postprandial peaks observed with diet SH. The response to level of protein supplementation would suggest that the increased concentrations of plasma insulin were due to greater absorption of amino acids from the small intestine. A correlation between protein absorption at the small intestine and plasma insulin concentrations has also been noted in sheep by Bassett et al. (1971), and Berzins \& Manns (1979) observed marked increases in pancreatic insulin secretion when amino acids were infused intravenously or into the duodenum. However, it is unlikely that the sudden postprandial rise in insulin concentration is a direct response to amino acid absorption as this would be a slower, continuous process. Moreover, plasma amino acids do not increase significantly after eating (Bassett, 1972). It appears more likely that the insulin response is 
due to the absorption of some other nutrient or to the influence of some other hormone, as yet unidentified, produced by the gastrointestinal tract in the presence of amino acids. Whatever the cause, the elevated concentrations of plasma insulin following the $\mathrm{SH}$ diet were sufficient to move the partitioning of nutrients towards body tissues in this group.

The results of the present experiment could help to explain why the response to protein supplementation varies with energy status of the cow. Orskov et al. (1981) found that increasing the supply of undegradable protein induced further loss of live weight in cows with low-energy intakes but not in those with higher energy intakes. Differences in energy intake were achieved by varying the proportions of concentrates and forage. Similarly, Krohn \& Anderson (1978) considered the response in milk production to three rates of protein supplementation at each of three rates of energy intake. Intake of energy was increased by supplying extra concentrates while maintaining forage intake. At the lowest energy intake, increased protein resulted in greater live-weight loss and increased fatcorrected milk (FCM) production. As energy intake was increased, the increase in FCM yield and live-weight loss with increased protein supply became smaller. Using the values of Krohn \& Anderson (1978), Oldham \& Smith (1982) found that adjustment of FCM yield to zero live-weight change resulted in a near linear response to FCM yield to increased $\mathrm{CP}$ intake. This suggests that with high-forage diets, response to protein concentration by increased FCM yield was exaggerated by enhanced live-weight loss but this did not occur with low-forage diets because of the changed hormonal status which favoured the partitioning of nutrients towards body tissues.

In conclusion, the results of the present study suggest that different carbohydrate sources, in particular starch $v$. fibre, and the forage:concentrate ratio, can promote different patterns of fermentation in the rumen, thereby influencing the hormonal status of the animal and affecting the response in milk production and live-weight change to increased protein supply. It is clear that factors other than protein and energy concentrations per se need to be considered when predicting animal responses, such as the interrelationship between protein and energy sources.

\section{REFEREN CES}

Agricultural Research Council (1980). The Nutrient Requirements of Ruminant Livestock. Slough: Commonwealth Agricultural Bureaux.

Agricultural Research Council (1984). The Nutrient Requirements of Ruminant Livestock, Suppl. no. 1. Slough: Commonwealth Agricultural Bureaux.

Bassett, J. M. (1972). Plasma glucagon concentrations in sheep: their regulation and relation to concentrations of insulin and growth hormone. Australian Journal of Biological Science 25, 1277-1287.

Bassett, J. M., Weston, R. H. \& Hogan, J. P. (1971). Dietary regulation of plasma insulin and growth hormone concentrations in sheep. Australian Journal of Biological Science 24, 321-330.

Beeby, J. M. \& Swan, H. (1983). Hormone and metabolite concentrations in beef steers of two maturity types under two systems of production. Animal Production 37, 345-351.

Berzins, R. \& Manns, J. G. (1979). How concentrate feeding affects glucoregulatory hormones in ruminants: implications in bovine ketosis. Journal of Dairy Science 62, 1739-1745.

Bhittacharya, A. N. \& Alulu, M. (1975). Appetite and insulin-metabolite harmony in portal blood of sheep led high or low roughage diets with or without intraruminal infusion of VFA. Journal of Animal Science 41, 225.233.

Cheong, F. H. \& Salt, F. J. (1968). A rapid wet digestion method for the determination of chromic oxide in faeces. Laboratory Practice 17, 199-200.

Cowan, R. T., Reid, G. W., Greenhalgh, J. F. D. \& Tait, C. A. G. (1981). Effects of feeding level in late pregnancy and dietary protein concentration during early lactation on food intake, milk yield, live-weight change and nitrogen balance of cows. Journal of Dairy Research 48, 201-212.

Davis, C. L., Grenawalt, D. A. \& McCoy, G. C. (1983). Feeding value of pressed brewers' grains for lactating dairy cows. Journal of Dairy Science 66, 7379

Garnsworthy, P. C. \& Jones, G. P. (1987). The influence of body condition at calving and dietary protein supply on voluntary food intake and performance in dairy cows. Animal Production 44, 347-353. 
Jenny, B. F. \& Polan, C. E. (1975). Postprandial blood glucose and insulin in cows fed high grain. Journal of Dairy Science 58, 512-520.

Jones, G. P. \& Garnsworthy, P. C. (1988). The effects of body condition at calving and dietary protein content on dry-matter intake and performance in lactating dairy cows given diets of low energy content. Animal Production 47, 321-333.

Krohn, C. C. \& Anderson, P. E. (1978). Different amounts of energy and protein for dairy cows in early lactation. Beretning no. 475. Denmark: Statens Husdyrbrugsforsøg.

MacRae, J. C. (1983). The energy requirements of the lactating animal. In Recent Advances in Animal Nutrition, pp. 23-24 [D. J. Farrell and P. Vohra, editors]. Armidale, Australia: University of New England Publishing Unit.

Oldham, J. D., Broster, W. H., Napper, D. J. \& Siviter, J. W. (1979). The effects of a low protein ration on milk yield and plasma metabolites in Friesian heifers during early lactation. British Journal of Nutrition 42, 149-162.

Oldham, J. D. \& Smith, T. (1982). Protein-energy interrelationships for growing and lactating cattle. In Protein Contribution of Feedstuffs for Ruminants, pp. 103-130 [E. L. Miller, I. H. Pike and A. J. H. van Es, editors]. London: Butterworths.

Ørskov, E. R., Hughes-Jones, M. \& McDonald, I. (1981). Degradability of protein supplements and utilisation of undegraded protein by high-producing dairy cows. In Recent Advances in Animal Nutrition - 1980, pp. 85-98 [W. Haresign, editor]. London: Butterworths.

Orskov, E. R. \& McDonald, I. (1979). The estimation of protein degradability in the rumen from incubation measurements weighted according to rate of passage. Journal of Agricultural Science, Cambridge 92, 449-503.

Sutton, J. D., Bines, J. A., Morant, S. V., Napper, D. J. \& Givens, D. I. (1987). A comparison of starchy and fibrous concentrates for milk production, energy utilization and hay intake by Friesian cows. Journal of Agricultural Science, Cambridge 109, 375-386.

Sutton, J. D., Hart, I. C., Morant, S. V., Schuller, E. \& Simmonds, A. D. (1988). Feeding frequency for lactating cows: diurnal patterns of hormones and metabolites in peripheral blood in relation to milk-fat concentration. British Journal of Nutrition 60, 265-274.

Sutton, J. D., Oldham, J. D. \& Hart, I. C. (1980). Products of digestion, hormones and energy utilisation in milking cows given low roughage diets. In Energy Metabolism, pp. 303-306 [L. E. Mount, editor], London: Butterworths.

Trenkle, A. (1970). Effects of short-chain fatty acids, feeding, fasting and type of diet on plasma insulin levels in sheep. Journal of Nutrition 100, 1323-1330. 